IRA-International Journal of Education \& Multidisciplinary Studies

ISSN 2455-2526; Vol.03, Issue 03 (2016)

Institute of Research Advances

http://research-advances.org/index.php/IJEMS

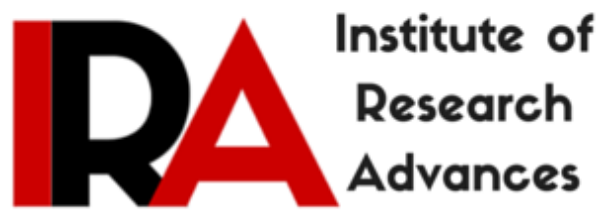

\title{
Relationship between Socio Economic Status and Academic Achievement
}

\section{T. J. M. S. Raju,}

Department of Education, Sikkim University, Gangtok-737 102, Sikkim State, India.

DOI: $\underline{\text { http://dx.doi.org/10.21013/jems.v3.n3.p2 }}$

\section{How to cite this paper:}

Raju, T. (2016). Relationship between Socio Economic Status and Academic Achievement. IRA International Journal of Education and Multidisciplinary Studies (ISSN 2455-2526), 3(3). doi:http://dx.doi.org/10.21013/jems.v3.n3.p2

(C) Institute of Research Advances

\section{(cc) EY-NC}

This works is licensed under a Creative Commons Attribution-Non Commercial 4.0 International License subject to proper citation to the publication source of the work.

Disclaimer: The scholarly papers as reviewed and published by the Institute of Research Advances (IRA) are the views and opinions of their respective authors and are not the views or opinions of the IRA. The IRA disclaims of any harm or loss caused due to the published content to any party. 


\begin{abstract}
The present study aimed at the relationship between the socio-Economic Status and Academic Achievement among secondary school students of Prakasam District of Andhra Pradesh, India. A number of investigations conducted so far in the field of Socio Economic Status (SES) indicated a significant relation between achievement and SES. After independence the SES of secondary school students in both urban and rural areas have registered a remarkable change. On account of phenomenal advancement in science and technology the conditions of the people have changed a lot.

The data were collected from 200 secondary school students by using the tools socio-economic status tool measures the dimensions of educational, economic, social, cultural and occupational determinants. The academic achievement tool consists of the test items of mathematics, general science and social studies. Later the data were analyzed with the statistical procedures like mean, standard deviations, critical ratios, Chi-square test and r-values. The results were discussed according to the significant values. Based on the results certain conclusions were drawn. Over all observation of the study some educational implications were given.
\end{abstract}

Key Words: Socio-economic status, Academic Achievement, High Class, Middle Class, Lower Class, Educational Determinants, Economic Determinants, Social Determinants, Cultural Determinants and Occupational Determinants

\title{
Introduction:
}

Socio economic status is the social as well as economic order of people who are believed to be and are accordingly ranked by all members of the community in socially superior or inferior positions. It is an all inclusive hierarchy which ranks all the members of the society into a vertical services or horizontal layers. The persons belonging to a particular class behave differently from members of other class. They differ in their style of life which includes factors like occupation or profession, income, consumption of goods, family rituals, manners and customs and social intercourse which includes social customs, exchange of social cultures, social parties etc.

Academic achievement is the students' capability of the instruction in the class room. It is the general educational achievement and the area most commonly covered by academic curricula. In the schools, the general method used to assess the academic achievement is the examination. The marks that the pupil gets in the examination are normally considered to be an indicator of his achievement. The standardized and teacher made tests were used to measure the class room achievement of the pupils.

Nigam et al (2001) found that there was no significant difference found between cognitive developments of rural, urban children of high as well as low SES. There exists significant difference in the cognitive development between rural and urban boys of high socio-economic status. But rural and urban boys of low SES were not found significantly. Rural and urban girls of both high and low SES were not found statistically different in their cognitive development. 
Aswal (2001) found that the relation between intelligence and achievement in mathematics may across different SES levels as three colleges reflected significant difference among different levels of SES out of five colleges in intelligence and achievement in mathematics.

Duhan et al (2001) found that more educated parents from economic back ground are able to provide more facilities as well as stimulation to their children than parents with poor education and of low economic background.

Lal channa (2002) found that female players of Varanasi of different levels with each other in achievement motivation level. But not in their Socio-economic conditions. It was also found that SES of female players of Varanasi was not associated or related with their game performance.

Santhi and Uijayal (2002) found that there was no significant correlation between formation of concepts in science and SES on the whole as well as separately between formation of concept in science and parents' profession and parents' education.

\section{Problem:}

The problem considered was a study of relationship between the socio-economic status and Academic achievement among secondary school students in Prakasam District of Andhra Pradesh, India.

\section{Variables:}

Two variable gender (Boys and Girls) and locality (urban and rural) are the demographical variables of the study.

\section{Objectives:}

- To find out the comparisons of variables across Academic achievement.

- To find out the association of SES with Academic achievement.

- To find out the relationship between SES and Academic achievement.

\section{Hypotheses:}

- There will be no significant difference between different variables of SES and academic achievement.

- There will be no significant difference between the association of SES and academic achievement.

- There will be no significant relationship between SES and Academic achievement.

\section{Tools used:}

Two scales are used in the present study. The socio-economic status consisting of 24 items with five sections viz. Educational Determinants, Economic Determinants, Social Determinants, Cultural Determinants and Occupational Determinants. The scoring will be in the order of social and economic aspects given in the key. According to the total scores 
obtained, students who scored 51-65 marks is placed in upper class between 36-50 marks placed in middle class and between 21-35 were placed in lower class in the classification of SES.

The Academic achievement tool consists of 50 Items. The test consists of 22 Items from knowledge, 17 items from understanding and 11 Items related to application level from Taxonomy of educational objectives. The Items are taken from mathematics (17 Items), General science (17 Items) and social studies (16 Items).Each Items has given ' 1 ' mark so the range of score was in between 0-50 marks, and the reliability of this achievement test is 0.76 .

\section{Administration:}

The two scales are combined and given to the students. Proper instructions were given to the students while giving their responses. First the SES tool responses were taken then the test related to academic achievement was conducted. Whenever the doubts raised by the students the investigator clarified on the spot. After completing the test the investigator collected the two questionnaires. Likewise the data were collected from six schools. Out of six schools three schools from urban and three schools from rural areas were taken for the study.

\section{Sample:}

The sample consists of 200. The sample consists of 100 boys and 100 girls, 100 urban students and 100 rural students. The sample is collected by way of satisfied random sampling method. The size of the sample is appropriate for the present study.

\section{Statistical procedures:}

The statistical procedures like means, standard deviations, CR-values, chi-square test and corrections were calculate to test the various hypotheses framed. The statistical procedures were done according to the formulas and guidelines given in Guilford (1978) and Garret (1988).

\section{Limitations of the study:}

- The study is limited to 6 high schools in Prakasam District and 200 secondary school students were taken for the sample.

- Only the variables gender and locality were taken for the study.

\section{Results and Discussion:}

Table - 1

Comparison of class and locality in Academic achievement

\begin{tabular}{|c|c|c|c|c|c|c|}
\hline S.No & Variable & Category & N & Mean & SD & CR \\
\hline \multirow{2}{*}{1} & \multirow{2}{*}{ SES } & Upper class & 55 & 62.69 & 18.21 & \multirow{2}{*}{$4.91^{* *}$} \\
\cline { 3 - 6 } & Middle class & 92 & 47.65 & 17.50 & \\
\hline
\end{tabular}


IRA-International Journal of Education \& Multidisciplinary Studies

\begin{tabular}{|c|c|c|c|c|c|c|}
\hline \multirow{2}{*}{2} & \multirow{2}{*}{ SES } & Upper class & 55 & 62.69 & 18.21 & \multirow{2}{*}{$7.81 * *$} \\
\hline & & Lower class & 53 & 38.46 & 13.91 & \\
\hline \multirow{2}{*}{3.} & \multirow{2}{*}{ SES } & Middle class & 92 & 47.65 & 17.50 & \multirow{2}{*}{$3.48 * *$} \\
\hline & & Lower class & 53 & 38.46 & 13.91 & \\
\hline \multirow{2}{*}{4.} & Locality \& & Urban upper & 38 & 65.81 & 18.98 & \multirow{2}{*}{$2.87 * *$} \\
\hline & Upper Class & Rural upper & 17 & 52.26 & 14.79 & \\
\hline \multirow{2}{*}{5} & \multirow{2}{*}{$\begin{array}{c}\text { Locality \& } \\
\text { Middle Class }\end{array}$} & Urban middle & 42 & 51.10 & 19.23 & \multirow{2}{*}{1.86} \\
\hline & & Rural middle & 50 & 43.92 & 17.48 & \\
\hline \multirow{2}{*}{6} & Locality \& & Urban lower & 20 & 40.5 & 13.56 & \multirow{2}{*}{0.82} \\
\hline & Lower Class & Rural lower & 33 & 37.2 & 14.85 & \\
\hline
\end{tabular}

$* * \mathbf{P}<\mathbf{0 . 0 1}$

Table: 2, Comparison of class and gender in their Academic Achievement

\begin{tabular}{|c|c|c|c|c|c|c|}
\hline S.No & Variable & Category & $\mathbf{N}$ & Mean & S.D & CR \\
\hline \multirow{2}{*}{1} & \multirow{2}{*}{$\begin{array}{l}\text { Upper class \& } \\
\text { Gender }\end{array}$} & Upper class boys & 28 & 65.58 & 18.94 & \multirow{2}{*}{1.09} \\
\hline & & Upper class girls & 27 & 60.42 & 16.13 & \\
\hline \multirow{2}{*}{2} & \multirow{2}{*}{$\begin{array}{l}\text { Middle class } \\
\text { \&Gender }\end{array}$} & Middle class boys & 41 & 46.40 & 18.72 & \multirow{2}{*}{0.62} \\
\hline & & Middle class girls & 51 & 48.81 & 18.32 & \\
\hline \multirow{2}{*}{3} & \multirow{2}{*}{$\begin{array}{c}\text { Lower class \& } \\
\text { Gender }\end{array}$} & Lower class boys & 31 & 38.04 & 15.56 & \multirow{2}{*}{0.11} \\
\hline & & Lower class girls & 22 & 38.50 & 12.89 & \\
\hline \multirow{2}{*}{4} & \multirow{2}{*}{$\begin{array}{l}\text { Upper class, } \\
\text { locality \& gender }\end{array}$} & Urban Upper class boys & 21 & 68.30 & 19.85 & \multirow{2}{*}{0.92} \\
\hline & & Urban Upper class girls & 17 & 62.74 & 17.32 & \\
\hline \multirow{2}{*}{5} & \multirow{2}{*}{$\begin{array}{l}\text { Middle class, } \\
\text { locality \& gender }\end{array}$} & Urban Middle class boys & 18 & 48.38 & 18.41 & \multirow{2}{*}{1.15} \\
\hline & & Urban Middle class girls & 24 & 55.30 & 20.36 & \\
\hline \multirow{2}{*}{6} & \multirow{2}{*}{$\begin{array}{l}\text { Lower class, } \\
\text { locality \& Gender }\end{array}$} & Urban Lower class boys & 11 & 39.04 & 12.20 & \multirow{2}{*}{0.34} \\
\hline & & Urban Lower class girls & 9 & 41.16 & 14.75 & \\
\hline
\end{tabular}


IRA-International Journal of Education \& Multidisciplinary Studies

\begin{tabular}{|c|c|c|c|c|c|c|}
\hline 7 & $\begin{array}{c}\text { Upper class, } \\
\text { locality \& Gender }\end{array}$ & Rural Upper class boys & 7 & 48.78 & 12.85 & \multirow{2}{*}{1.05} \\
\cline { 3 - 6 } 8 & Rural Upper class girls & 10 & 55.50 & 13.00 & \\
\hline \multirow{2}{*}{8} & $\begin{array}{c}\text { Middle class, } \\
\text { locality \& Gender }\end{array}$ & Rural Middle class boys & 23 & 44.90 & 18.78 & \multirow{2}{*}{0.38} \\
\cline { 3 - 5 } & & Rural Middle class girls & 27 & 43.01 & 15.30 & \\
\hline 9 & $\begin{array}{c}\text { Lower class, } \\
\text { locality \& Gender }\end{array}$ & Rural Lower class boys & 20 & 37.50 & 17.05 & \multirow{2}{*}{0.12} \\
\cline { 3 - 5 } & & Rural Lower class girls & 13 & 36.88 & 11.06 & \\
\hline
\end{tabular}

Not Significant

The mean, standard deviations and critical ratio values of the academic achievement in respect to class and locality variables were tabulated in table-1.The variable SES in all the classes and upper classes of urban and rural were differed significantly. So the null hypotheses framed on these variables were rejected. The remaining variables middle and lower classes of locality were not differed significantly. So the null hypotheses framed on these variables were accepted.

The mean, standard deviations and critical ratio values of the academic achievement in respect to class and gender variables were tabulated in table-2.It can be observed that all the variables of upper, middle and lower classes of gender were not differed significantly. So the null hypotheses framed on these variables were accepted.

Table: 3

Association between SES and Academic Achievement

\begin{tabular}{|c|c|c|c|c|}
\hline Categories & $\begin{array}{c}\text { High } \\
\text { Achievement }\end{array}$ & $\begin{array}{c}\text { Average } \\
\text { Achievement }\end{array}$ & Low Achievement & Total \\
\hline High SES & $34(19.25)$ & $16(21.17)$ & $5(14.57)$ & 55 \\
\hline $\begin{array}{c}\text { Average } \\
\text { SES }\end{array}$ & $29(32.21)$ & $38(35.42)$ & $25(24.38)$ & 92 \\
\hline Low SES & $7(18.55)$ & $23(20.40)$ & $23(14.04)$ & 53 \\
\hline Total & 70 & 77 & 53 & 200 \\
\hline
\end{tabular}

The obtained df value is $\mathbf{3 2 . 2 7}$.

The chi-square values of association between SES and academic achievement were tabulated in table-3.The obtained chi-square value 32.27 is greater than the table value of 9.48 at 0.05 level and the null hypothesis is rejected i.e. there is a significant association between the level of SES and level of academic achievement in school subjects. 
Table: 4

The Relationship between SES and Academic achievement

\begin{tabular}{|c|c|c|c|}
\hline S.No. & Parameters & N & r-value \\
\hline 1 & SES & & \\
\cline { 1 - 2 } 2 & Academic achievement & 200 & 0.40 \\
\hline
\end{tabular}

The correlation value between socio economic status and academic achievement was tabulated in table-4.The co-efficient of correlation between SES and Academic achievement was 0.40 which is positive. So there is a positive relationship between the higher the SES, the higher the Academic achievement.

\section{Conclusions:}

- There are significant differences between upper class and middle class, upper class and lower class, middle class and lower class and urban upper class and rural upper class in academic achievement.

- There are no significant differences between class and gender, and class, locality and gender in academic achievement.

- There is significant association between socio-economic status and academic achievement.

- There is a positive relationship between the SES, the Academic Achievement.

\section{Educational Implications:}

- Individualized instruction and institutional tuitions would improve the attainment of pupils from low SES.

- Counselors should appoint in each school for providing suitable guidance for low SES diagnostic and remedial teaching can benefit for some pupils.

- Parental Co-operation has to be made more effective through parent-teacher association and ensure proper environment at home for effective study.

\section{References:}

Aswal, G.S. (2001). Intelligence as a correlate of achievement in mathematics across different levels of SES. Psycho lingua, Vol: 31(2) P: 127-130.

Duhan, Krishna, Balda, Santhi (2001). Parental stimulation socio- economic level and language development of pre- school children. Psycho lingua, Vol: 3(1) P: 37-40.

Lal, Channa (2002). Effect of achievement motivation and socio-economic status on sports performance of sportsman. Ph.D. Physical education, B.H. University, Banaras. 
Nigam, Vibha and Reena (2001). Cognitive development in children in relation to SES. Psycho lingua, Vol : 31(1) P : 69-72.

Santhi, S and Ujjayal, P. (2002). Formation of concepts in science and SES in primary school students. Indian educational Review, Vol : XL(2) P : 66-70.

Guilford, J.P (1978).Fundamental Statistics in Psychology and Education, Mc-Graw Hill Publishing Co, Tokyo, Japan.

Garret, H.E. (1988). Statistics in Psychology and Education, International book Bureau, Hyderabad. 